$1-1-1966$

\title{
Some microbiological, chemical, and physical investigations of farm ponds
}

\author{
H. A. Wilson
}

Terry Miller

Rosa Thomas

Follow this and additional works at: https://researchrepository.wvu.edu/ wv_agricultural_and_forestry_experiment_station_bulletins

\section{Digital Commons Citation}

Wilson, H. A.; Miller, Terry; and Thomas, Rosa, "Some microbiological, chemical, and physical investigations of farm ponds" (1966). West Virginia Agricultural and Forestry Experiment Station Bulletins. 522T.

https://researchrepository.wvu.edu/wv_agricultural_and_forestry_experiment_station_bulletins/663 @ WVU. It has been accepted for inclusion in West Virginia Agricultural and Forestry Experiment Station Bulletins by an authorized administrator of The Research Repository @ WVU. For more information, please contact ian.harmon@mail.wvu.edu. 
West Virginia University Libraries

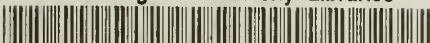

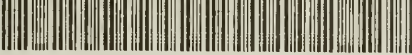

$\begin{array}{lll}30802 & 1008961379\end{array}$ 
Digitized by the Internet Archive in 2010 with funding from Lyrasis Members and Sloan Foundation 


$$
\begin{aligned}
& \text { Ag-Eng. Iibrany } \\
& \text { West Virginia University }
\end{aligned}
$$

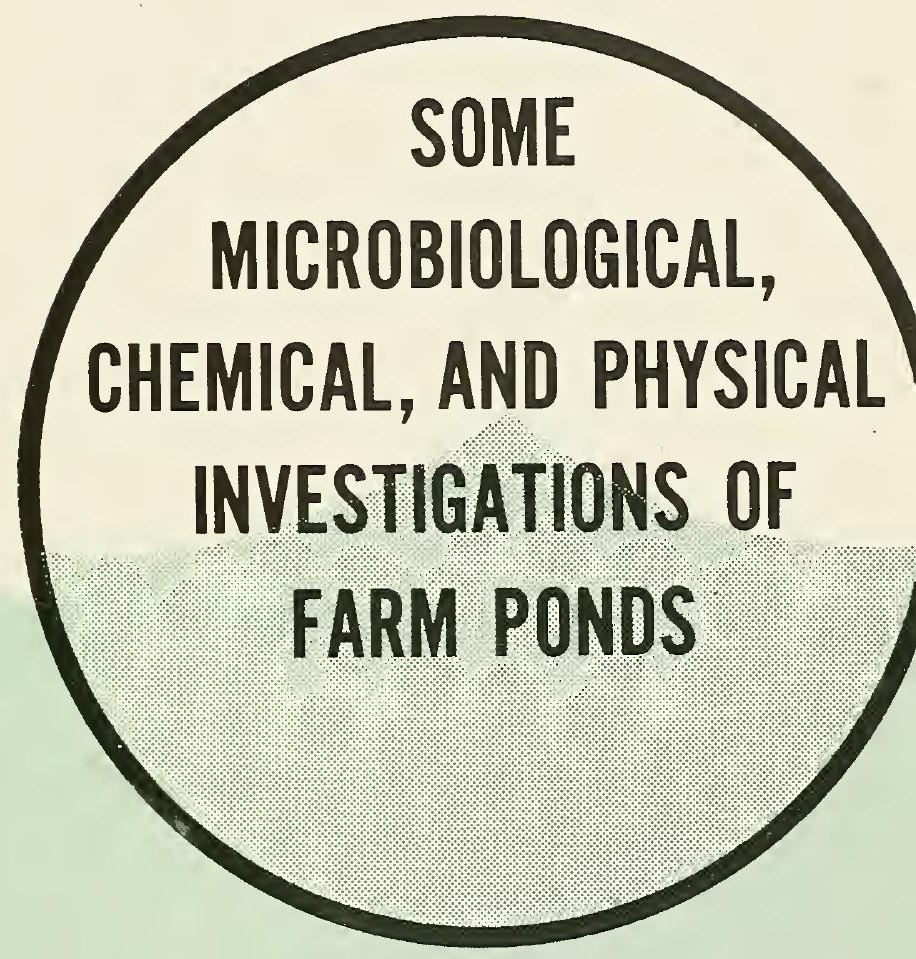

WEST VIRGINIA UNIVERSITY AGRICULTURAL EXPERIMENT STATION 


\section{The Authors}

The authors of Some Microbiological, Chemical, and Physical Investigations of Farm Ponds are-

H. A. Wilson, Bacteriologist in the West Virginia University Agricultural Experiment Station.

Terry Miller, former graduate assistant. Present address: The Division of Natural Sciences, 103 George Hubbard Clapp Hall, University of Pittsburgh. Pittsburgh. Pa.

Rosa Thomas, former National Science Foundation Undergraduate Research Participant. Present address: Department of Dairy Science, Kansas State University, Manhattan, Kan.

\section{Acknowledgment}

The authors wish to thank Dr. Everett M. Jencks and Mrs. Maria H. Cartledge of the Department of Agronomy and Genetics for the exchange capacity determinations.

West V'irginia UNmersity

Agricultural Experiment Station

College of Agricilti:re aNd Forestry

A. H. VanLandinghail, Diregtor

MORGANTOWN 


\section{Contents}

SUMMARY AND CONCLUSIONS $\ldots \ldots \ldots \ldots \ldots \ldots \ldots$

INTRODUCTION $\ldots \ldots \ldots \ldots \ldots \ldots \ldots \ldots \ldots \ldots \ldots \ldots \ldots \ldots \ldots \ldots \ldots \ldots$

METHODS $\ldots \ldots \ldots \ldots \ldots \ldots \ldots \ldots \ldots \ldots \ldots \ldots \ldots \ldots \ldots \ldots \ldots \ldots \ldots \ldots \ldots$

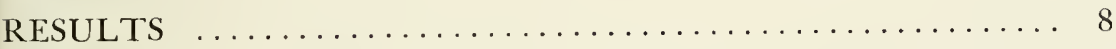

Bacterial Numbers $\ldots \ldots \ldots \ldots \ldots \ldots \ldots \ldots \ldots \ldots \ldots \ldots$

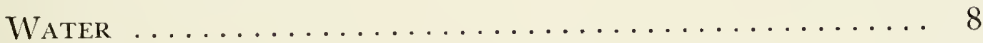

SEDIMENT $\ldots \ldots \ldots \ldots \ldots \ldots \ldots \ldots \ldots \ldots \ldots \ldots \ldots \ldots \ldots \ldots$

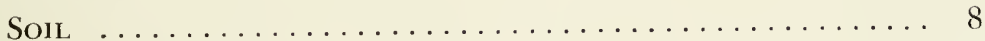

Nonchronogenic : Chromogenic Ratio ............. 8

The Relation of Depth and Numbers ............. 8

Decomposition Studies $\ldots \ldots \ldots \ldots \ldots \ldots \ldots \ldots \ldots \ldots \ldots \ldots$

Straw and Red Clover .................. 11

Algae and Potamogeton $\ldots \ldots \ldots \ldots \ldots \ldots \ldots \ldots \ldots \ldots \ldots$

Nutritional Investigations and Nutritional Grouping . . . . 12

Mediun Concentration $\ldots \ldots \ldots \ldots \ldots \ldots \ldots \ldots \ldots \ldots \ldots$

Physical and Chemical Characteristics of Pond Sediment ... 13 DISCUSSION $\ldots \ldots \ldots \ldots \ldots \ldots \ldots \ldots \ldots \ldots \ldots \ldots \ldots \ldots \ldots \ldots \ldots \ldots \ldots$

LITERATURE CITED $\ldots \ldots \ldots \ldots \ldots \ldots \ldots \ldots \ldots \ldots \ldots \ldots \ldots$ 


\section{Summary and Conclusions}

Farm ponds, like other surface fresh waters, possess an indigenous microflora. Although considerable variation occurs, the approximate range of bacterial density is from 5 thousand to 30 thousand cells per milliliter. Little or no correlation was found between the numbers of bacteria and depth of $\mathrm{pH}$ of the water. The ratio of nonchromogenic/ (hromogenic bacteria was smaller in water and larger in watershed soil. Most of the bacterial isolates from water, sediment, and soil required the factors in yeast and/or soil extract for growth and varied considerably in their ability to grow in a dilute liquid medium. The decomposition rate of plant residues in pond water apparently depends upon the composition of the residues. The bottom sediment belongs to the finer classes of soil material. The average inorganic carbon/nitrogen ratio of bottom sediment ranged from $11-13 / 1$ and was near to the 9-11/1 median as reported for soils. The phosphorus content and the exchangeable ion status of the bottom sediments varied greatly and there was no correlation with any of the other determinations made. 


\section{Some Microbiological, Chemical, and Physical Investigations of Farm Ponds}

\section{H. A. Wilson, Terry Miller, and Rosa Thomas}

\section{Introduction}

F AR.M PONDS, familiar man-made structures, are appearing in ever$\mathrm{F}$ increasing numbers on farmsteads in the United States and Canada. The original use of most ponds was for livestock watering, either throughout the year or during periods of drought. Some are now used for irrigation purposes and as domestic water supplies (Bennett 1962; Malaney et al. 1962). Today, however, as people have become more and more recreation-minded farm ponds are used extensively for swimming, fishing, and ice skating.

The public health aspects of various water sources have been studied extensively but fundamental research of the indigenous bacteria has engaged the attention of only a few workers.

Taylor (1940) studied the distribution of bacteria in English lakes. In 1942 he studied the relationship between the bacteria in lakes and streams and the soil microflora. Potter and Baker (1956) determined the number of bacteria, actinomycetes, and fungi in the water, mud, and soil of Flathead and Rogers lakes in Montana. They also reported the percentage of the total bacteria that were pigment producers. Boyd and Boyd (1963) made a thorough bacteriological study of an arctic coastal lake. They found bacteria that were common to temperate regions, as well as coliforms and enteric pathogens.

Snow and Fred (1926) noted that more pigmented bacteria were isolated from Lake Mendota, Wisconsin, water than from soil. Henrici and McCoy (1938) found the microbial population of the bottom sediments to be dense as compared to the population in the water. Potter and Baker (1956) also reported that the numbers of bacteria in the bottom mud were much larger than those in the water of Flathead and Rogers lakes.

According to Zobell (1946), Duggeli attempted to determine the abundance of certain physiological types of bacteria in Lake Ritom, Switzerland. Although species identification, especially coliforms or enterococci, is important, the grouping of isolates on a physiological nutritional basis as attempted by Duggeli and by Lochhead and Chase (1943) 
for soil microorganisms would probably be more useful in the study of the saprophytic pond or lake water bacteria. The saprophytic bacteria are responsible for the decomposition of organic compounds in the water, and therefore they are of importance in the nutritional cycle. Taylor (1942) goes so far as to state that the usual methods of classification are of little value in the study of water bacteriology.

This bulletin reports microbiological data on farm pond water and watershed soil, and some microbiological, chemical, and physical characteristics of pond bottom sediments.

\section{Methods}

The ponds chosen for this study were near enough to the laboratory so that little more than an hour passed between sample collection and plating.

The characteristics of the ponds studied were as follows:

Pond No. 1 has a small watershed and is primarily spring fed; the water is used for nonconsumable purposes around a home, coffee shop, and cabins.

Pond No. 2 is located in the University Arboretum and is used for fishing and swimming.

Pond No. 3 is one of three in a series of five flood control ponds but is also used for fishing and swimming.

Ponds No. 4 and 5 are the middle and lower ponds, respectively, in a series of three ponds for flood control; considerable fishing is done in both and some swimming in No. 5 .

Pond No. 6 is on the University's Animal Husbandry Farm and is used some for fishing; considerable algae (pond scum) are present most of the time and drainage into the pond is from a pastured area. Stock occasionally gets into the pond enclosure.

Pond No. 7 is used primarily for recreational purposes and drainage is possible from the house and barn following heary rains.

No attempt was made to obtain comparable clata on certain other ponds used in this study. All of the ponds, however, are of typical farm pond construction.

All water samples were collected in sterile glass containers, usually from a boat at approximately pond center and 6 to 8 inches below the surface. The bottom sediment was also collected from a boat by means of a can attached to a long pole. Each sample was a composite of three or four subsamples taken from different places in the pond. After the sample had settled the excess water was poured off. Each watershed soil sample also was a composite of subsamples taken 0 to 4 
inches deep from around the pond, the distance from the water's edge varying from 2 to 10 feet. Sediment and soil samples were not obtained each time a water sample was collected.

Two separate studies were made at different times to determine the bacterial numbers in farm pond waters. Sodium caseinate agar (Taylor 1940) was used in the first study to determine the bacterial density. The petri plates were incubated at $20 \mathrm{C}$ for 14 days in a closed container and the humidity was maintained at a high level by means of free water in the container bottom. Nutrient agar was used in the second study and the incubation periods were 7,8 , or 11 days.

The decomposition rate of oat straw, red clover, potamogeton, and algae when added to pond water was determined. Each material was ground in a Wiley mill to pass a 20 -mesh sieve. Two grams of ground material was added to each of several sterile 250-ml Erlenmeyer flasks (Burkholder and Bornside 1957). To each flask $50 \mathrm{ml}$ of freshly collected pond water was added and the flask and contents placed on a reciprocal shaker (20 oscillations per minute) in a $30 \mathrm{C}$ constant temperature room. Duplicate flasks were removed after 2, 4, 6, 8, 15, and 22 days incubation. The contents of each flask were carefully transferred to a tared $100-\mathrm{ml}$ beaker, the $\mathrm{pH}$ determined, and the contents dried to a constant weight at $70 \mathrm{C}$. The loss in weight, based upon the $2 \mathrm{gm}$ original weight, was considered as loss by decomposition.

Bacterial isolates from water, sediment, and soil were placed into nutritional groups, using the media suggested by Lochhead and Chase (1943) for rhizosphere studies. The isolates were first transferred from the stock cultures to a semisolid medium and after 24 hours of growth these were inoculated into the various nutritional grouping media. The cultures were incubated at $25 \mathrm{C}$ for five days.

Soil moisture was determined by drying the soil to constant weight at $105 \mathrm{C}$ to $110 \mathrm{C}$. The soil $\mathrm{pH}$ was determined on a soil : water ratio of 1 : 1.5 , after standing, with frequent shaking, for 1 hour. The determination was made electrometrically, using a glass electrode.

Some physical and chemical characteristics of bottom sediments from 27 ponds were determined. The texture classes of the sediments were based upon their mechanical analysis, as determined by the hydrometer method (Bouyoucos 1936). Organic carbon was determined by a wet combustion method (Allison 1960) and total nitrogen by a Kjeldahl procedure. The active and reserve phosphorus determinations were made upon a HCl-NH$H_{t}$ F extract of the sediments (Graham 1959). The exchangeable calcium, magnesium, and potassium, and the exchange capacity of the bottom sediments were determined upon an ammonium acetate leachate by means of flame photometry using an oxygen-hydrogen flame. 


\section{Results}

\section{Bacterial Numbers}

Ilater. In Table 1 are presented the numbers of bacteria found in farm pond water using sodium caseinate agar as a plating medium.

White colonies predominated, except in Pond 4 where the number of bacteria in one of the two samples was excessively high. Excluding this pond, the nonchromogenic bacteria ranged from 53 to 82 per cent of the total colony count. Bacteria producing yellow colonies were the next most numerous, followed by those producing orange, red, and blue colonies.

Sediment. The number of bacteria found per gram of wet bottom sediment from five ponds plated on sodium caseinate agar is presented in Table 2. The average number of bacteria in the sediment may be 1,500 times as large as the average found in water. The nonchromogenic bacteria predominate and the yellow pigmented colonies predominated among the chromogens, however, their number was only about 20 per cent that of the nonchromogenic bacteria.

Soil. The total number of bacteria in the watershed soil, as determined on sodium caseinate agar, was somewhat greater than normally encountered in an arable soil (Table 3). On the other hand, the percentage of chromogens was much smaller than that found in either the water or sediment samples. The yellow pigment producers predominated among the chromogens as in the water and sediment, but only areraged 10.7 per cent of the total bacterial populations.

\section{Nonchromogenic : Chromogenic Ratio}

The nonchromogenic : chromogenic ratio varied, not only among samples taken the same day from different ponds but also among samples of the same pond obtained at different times. The ratio of nonchromogenic to chromogenic bacteria arcraged 1.47:1 among the water samples. 3.85:1 among the bottom sediment samples, and 6.55:1 among the soil samples.

\section{The Relation of Numbers and Depth}

In Table 4 are presented the numbers of bacteria at different depths at various times cluring the year.

The total number of bacteria at any depth and at any sampling period is not large, ranging from a low near 5 thousand bacteria per milliliter to a high of 30 thousand.

The average ratio of nonchromogenic to chromogenic bacteria for the different depths for each of the ponds was determined. The ratios 
Table 1. Average Number of Bacteria Per Milliliter OF FARM POND WATER.

(Sodium Caseinate Mediuni; Incubation at $20^{\circ} \mathrm{C}$ for 14 Days.)

\begin{tabular}{|c|c|c|c|c|c|c|c|c|}
\hline \multirow{2}{*}{ Pond } & \multirow{2}{*}{$\begin{array}{c}\text { Number } \\
\text { of } \\
\text { Samples }\end{array}$} & \multirow{2}{*}{$\begin{array}{c}\text { Total } \\
\text { Number } \\
\text { of } \\
\text { Bacteria }\end{array}$} & \multicolumn{5}{|c|}{ Pigment Producers } & \multirow{2}{*}{$\mathrm{pH}$} \\
\hline & & & White & Yellow & Orange & Red & Blue & \\
\hline 1 & 7 & 22,274 & 17,943 & 3,947 & 571 & 208 & 0 & 6.87 \\
\hline 2 & 4 & 11,004 & 7,110 & 2,823 & 551 & 300 & 31 & 8.34 \\
\hline 3 & 4 & 9,754 & 5,844 & 2,664 & 320 & 381 & 0 & 7.32 \\
\hline 4 & 2 & $44,820^{*}$ & 17,460 & 17,720 & 812 & 1,520 & 0 & 8.15 \\
\hline 5 & 3 & 13,895 & 8,080 & 3,569 & 775 & 546 & 0 & 7.67 \\
\hline 6 & 1 & 25,580 & 13,740 & 9,540 & 0 & 2,300 & 0 & 7.10 \\
\hline 7 & 1 & 6,920 & 5.020 & 1,460 & 0 & 440 & 0 & 7.70 \\
\hline \multicolumn{2}{|c|}{ Average } & 19,178 & 10,742 & 5,960 & 433 & 407 & 6 & \\
\hline
\end{tabular}

*One sampling count was 69,800 per $\mathrm{ml}$; the other 19,840 per ml.

Table 2. Average Number of Bacterla Per Wet Gram of Pond-Botton Sedinent.

(Sodium Caseinate Medium; Incubation at $20^{\circ} \mathrm{C}$ for 14 Days.)

\begin{tabular}{|c|c|c|c|c|c|c|c|c|}
\hline \multirow{2}{*}{ Pond } & \multirow{2}{*}{$\begin{array}{c}\text { Number } \\
\text { of } \\
\text { Samples }\end{array}$} & \multirow{2}{*}{$\begin{array}{c}\text { Total } \\
\text { Number } \\
\text { of } \\
\text { Bacteria }\end{array}$} & \multicolumn{5}{|c|}{ Pigment Producers } & \multirow{2}{*}{$\mathrm{pH}$} \\
\hline & & & White & Yellow & Orange & Red & Blue & \\
\hline $\begin{array}{l}1 \\
2 \\
3 \\
4 \\
5 \\
\end{array}$ & $\begin{array}{l}3 \\
2 \\
3 \\
3 \\
3 \\
\end{array}$ & $\begin{array}{c}(000) \\
16,361 \\
32,656 \\
62,570 \\
27,303 \\
16,187\end{array}$ & $\begin{array}{c}(000) \\
14,329 \\
2,194 \\
53,195 \\
22,955 \\
13,183 \\
\end{array}$ & $\begin{array}{l}(000) \\
1,637 \\
8,052 \\
8,083 \\
2,963 \\
1,953\end{array}$ & $\begin{array}{r}(000) \\
108 \\
1,239 \\
597 \\
255 \\
255 \\
\end{array}$ & $\begin{array}{r}(000) \\
322 \\
1 \\
695 \\
963 \\
185 \\
\end{array}$ & $\begin{array}{r}0 \\
0 \\
0 \\
13 \\
0 \\
\end{array}$ & $\begin{array}{l}6.33 \\
6.65 \\
6.62 \\
6.77 \\
6.77 \\
\end{array}$ \\
\hline \multicolumn{2}{|c|}{ Average } & 31,015 & 21,170 & 4,583 & 489 & 217 & 3 & \\
\hline
\end{tabular}

Table 3. Average Number of Bacteria Per Gram (oven-dry basis) of Watershed Soll.

(Sodium Caseinate Medium; Incubation at 20 C for 14 Days.)

\begin{tabular}{l|c|c|c|c|c|c|c|c}
\hline \hline \multirow{2}{*}{ Pond } & $\begin{array}{c}\text { Number } \\
\text { of } \\
\text { Samples }\end{array}$ & $\begin{array}{c}\text { Total } \\
\text { Number } \\
\text { of } \\
\text { Bacteria }\end{array}$ & \multicolumn{7}{c}{ Phite } & Yellow & Orange & Red & Blue & pH \\
\hline & & $(000)$ & $(000)$ & $(000)$ & $(000)$ & $(000)$ & & \\
1 & 5 & 17,400 & 14,910 & 1,798 & 164 & 89 & 62 & 5.52 \\
2 & 2 & 6,974 & 6,486 & 495 & 109 & 0 & 0 & 4.61 \\
3 & 3 & 25,342 & 22,241 & 3,120 & 734 & 3,900 & 0 & 5.50 \\
4 & 2 & 10,764 & 8,365 & 2,258 & 12 & 57 & 12 & 4.62 \\
5 & 2 & 25,210 & 22,580 & 1,965 & 663 & 0 & 0 & 5.15 \\
6 & 2 & 21,387 & 15,708 & 1,830 & 854 & 0 & 0 & 5.90 \\
\hline \multicolumn{2}{l}{ Average } & 17,831 & 15,048 & 1,911 & 423 & 371 & 12 & \\
\hline
\end{tabular}


ranged from 1.61:1 to 5.82:1. These ratios are higher than those obtained from the data reported in Table 1. It must be remembered, however, that both the plating media used and the incubation times were different.

Table 4. Bacterial Density, pH and Temperatlre of the Ponins

Determined at Various Depths at Different Seasons."

(Nutrient Agar Medium)

\begin{tabular}{|c|c|c|c|c|c|c|}
\hline \multirow{2}{*}{ Depth } & \multirow{2}{*}{ Date } & \multicolumn{3}{|c|}{ Bacteria } & \multirow{2}{*}{$\mathrm{pH}$} & \multirow{2}{*}{$\begin{array}{c}\text { Water } \\
\text { Temper- } \\
\text { ature } \\
{ }^{\circ} \mathbf{C}\end{array}$} \\
\hline & & $\begin{array}{l}\text { Total } \\
\times \quad 10^{3} \\
\end{array}$ & $\begin{array}{l}\text { White } \\
\times 10^{3} \\
\end{array}$ & \begin{tabular}{|c|} 
Pigmented \\
$\times 10^{\circ}$
\end{tabular} & & \\
\hline Surface & $\begin{array}{c}12 / 62^{b} \\
3 / 63^{c} \\
7 / 63^{b} \\
9 / 63^{d}\end{array}$ & $\begin{array}{r}7.4 \\
13.0 \\
8.1 \\
16.8 \\
\end{array}$ & $\begin{array}{c}\text { Pond } 1 \\
5.3 \\
9.4 \\
6.8 \\
11.8 \\
\end{array}$ & $\begin{array}{l}2.1 \\
3.6 \\
1.3 \\
5.0\end{array}$ & $\begin{array}{l}6.95 \\
7.05 \\
7.35 \\
6.85 \\
\end{array}$ & $\begin{array}{r}6.0 \\
12.5 \\
27.0 \\
19.0 \\
\end{array}$ \\
\hline $4 \mathrm{ft}$. & $\begin{array}{r}12 / 62 \\
3 / 63 \\
7 / 63 \\
9 / 63\end{array}$ & $\begin{array}{r}11.7 \\
18.1 \\
11.9 \\
8.9\end{array}$ & $\begin{array}{r}8.9 \\
14.2 \\
9.6 \\
7.7\end{array}$ & $\begin{array}{l}2.8 \\
3.9 \\
2.3 \\
1.2\end{array}$ & $\begin{array}{l}7.05 \\
6.90 \\
6.85 \\
7.10\end{array}$ & $\begin{array}{r}9.0 \\
15.0 \\
24.0 \\
21.5\end{array}$ \\
\hline $7.5 \mathrm{ft}$. & $\begin{array}{r}12 / 62 \\
3 / 63 \\
7 / 63 \\
9 / 63 \\
\end{array}$ & $\begin{array}{l}14.1 \\
21.3 \\
15.7 \\
19.3 \\
\end{array}$ & $\begin{array}{l}11.2 \\
16.6 \\
13.3 \\
13.7 \\
\end{array}$ & $\begin{array}{l}2.9 \\
4.7 \\
2.4 \\
5.6 \\
\end{array}$ & $\begin{array}{l}6.85 \\
6.75 \\
6.70 \\
6.80 \\
\end{array}$ & $\begin{array}{l}12.0 \\
16.0 \\
20.0 \\
23.5 \\
\end{array}$ \\
\hline Surface & $\begin{array}{r}12 / 62 \\
3 / 63 \\
7 / 63 \\
9 / 63 \\
\end{array}$ & $\begin{array}{l}16.1 \\
19.3 \\
22.5 \\
18.5 \\
\end{array}$ & $\begin{array}{c}\text { Pond 2 } \\
14.8 \\
15.6 \\
13.9 \\
11.6\end{array}$ & $\begin{array}{l}1.3 \\
3.7 \\
8.6 \\
7.2 \\
\end{array}$ & $\begin{array}{l}6.90 \\
6.90 \\
6.6 .5 \\
7.05 \\
\end{array}$ & $\begin{array}{r}5.0 \\
12.0 \\
26.0 \\
19.0\end{array}$ \\
\hline $4 \mathrm{ft}$. & $\begin{array}{r}12 / 62 \\
3 / 63 \\
7 / 63 \\
9 / 63\end{array}$ & $\begin{array}{l}19.3 \\
18.9 \\
23.7 \\
20.4\end{array}$ & $\begin{array}{l}14.1 \\
17.9 \\
16.4 \\
15.3\end{array}$ & $\begin{array}{l}5.2 \\
1.0 \\
7.3 \\
5.1\end{array}$ & $\begin{array}{l}6.95 \\
7.00 \\
6.60 \\
7.15\end{array}$ & $\begin{array}{r}8.5 \\
13.5 \\
21.5 \\
21.0\end{array}$ \\
\hline $8 \mathrm{ft}$. & $\begin{array}{r}12 / 62 \\
3 / 63 \\
7 / 63 \\
9 / 63 \\
\end{array}$ & $\begin{array}{l}27.0 \\
22.6 \\
29.1 \\
19.7 \\
\end{array}$ & $\begin{array}{l}22.9 \\
19.3 \\
14.7 \\
16.0\end{array}$ & $\begin{array}{r}4.1 \\
3.3 \\
14.4 \\
3.7 \\
\end{array}$ & $\begin{array}{l}6.50 \\
6.70 \\
6.45 \\
6.65 \\
\end{array}$ & $\begin{array}{l}11.5 \\
16.0 \\
10.5 \\
22.0 \\
\end{array}$ \\
\hline Surface & $\begin{array}{r}12 / 62 \\
3 / 63 \\
7 / 63 \\
9 / 63 \\
\end{array}$ & $\begin{array}{l}35.0 \\
79.0 \\
41.8 \\
48.6 \\
\end{array}$ & $\begin{array}{r}\text { Pond } 6 \\
23.4 \\
1.8 \\
28.8 \\
33.4 \\
\end{array}$ & $\begin{array}{l}11.6 \\
77.2 \\
13.0 \\
15.2 \\
\end{array}$ & $\begin{array}{l}7.15 \\
6.90 \\
6.85 \\
7.20 \\
\end{array}$ & $\begin{array}{r}7.0 \\
11.0 \\
24.0 \\
23.0 \\
\end{array}$ \\
\hline $4 \mathrm{ft}$. & $\begin{array}{r}12 / 62 \\
3 / 63 \\
7 / 63 \\
9 / 63 \\
\end{array}$ & $\begin{array}{l}39.4 \\
50.6 \\
34.4 \\
25.6 \\
\end{array}$ & $\begin{array}{l}27.6 \\
31.4 \\
25.0 \\
14.6 \\
\end{array}$ & $\begin{array}{r}11.8 \\
19.2 \\
9.4 \\
11.0 \\
\end{array}$ & $\begin{array}{l}7.20 \\
6.80 \\
7.05 \\
7.20 \\
\end{array}$ & $\begin{array}{l}10.0 \\
12.5 \\
21.5 \\
22.0 \\
\end{array}$ \\
\hline $6.5 \mathrm{ft}$. & $\begin{array}{r}12 / 62 \\
3 / 63 \\
7 / 63 \\
9 / 63\end{array}$ & $\begin{array}{l}40.8 \\
26.2 \\
41.4 \\
38.4\end{array}$ & $\begin{array}{l}27.6 \\
36.4 \\
31.0 \\
23.8\end{array}$ & $\begin{array}{r}13.2 \\
9.8 \\
10.4 \\
14.6\end{array}$ & $\begin{array}{l}6.80 \\
6.95 \\
6.90 \\
6.70 \\
\end{array}$ & $\begin{array}{l}13.5 \\
15.5 \\
20.0 \\
18.5\end{array}$ \\
\hline
\end{tabular}

${ }^{a}$ Abridged data from Terry Lee Miller; M.S. Thesis, Mest Virginia Lniversity. Murgantowu, West Virginia. 1964.

${ }^{\mathrm{b}} \mathrm{Plates}$ incubated $i$ davs at $20^{\circ} \mathrm{C}$.

CPlates incubated 8 dais at $20^{\circ} \mathrm{C}$.

${ }^{d}$ Plates incubated 11 dais at $20^{\circ} \mathrm{C}$. 


\section{Decomposition Studies}

The decomposition of straw and red clover was studied in water from ponds 1, 2, 3, 4, and 5; potamogeton from ponds 2 and 4; and algae from pond 5 .

Straw and red clover. The decomposition of straw and red clover in pond water is shown graphically in Figure 1. Although these data are from pond 1, similar results were obtained for the other ponds. In all instances, decomposition of both straw and red clover was fairly rapid, that of the red clover being more rapid for the first four to six days, after which the rate was slower. After 22 days about 9.5 per cent of the straw and 29.5 per cent of the red clover had decomposed. The $\mathrm{pH}$ of the water-plant residue mixture after two days of incubation was 7.20 and 7.35 for the red clover and straw, respectively, but both became more alkaline as decomposition progressed. In most instances, the values fluctuated from one sampling time to the next.

The slower rate of decomposition of oat straw, as compared to red clover, was thought to be the result of its lower nitrogen content. Oat straw contains about 0.6 per cent nitrogen and red clover about 2.1 per cent (van Slyke 1939). The biological nitrogen demand is satisfied if organic materials contain approximately 1.7 per cent nitrogen. Less

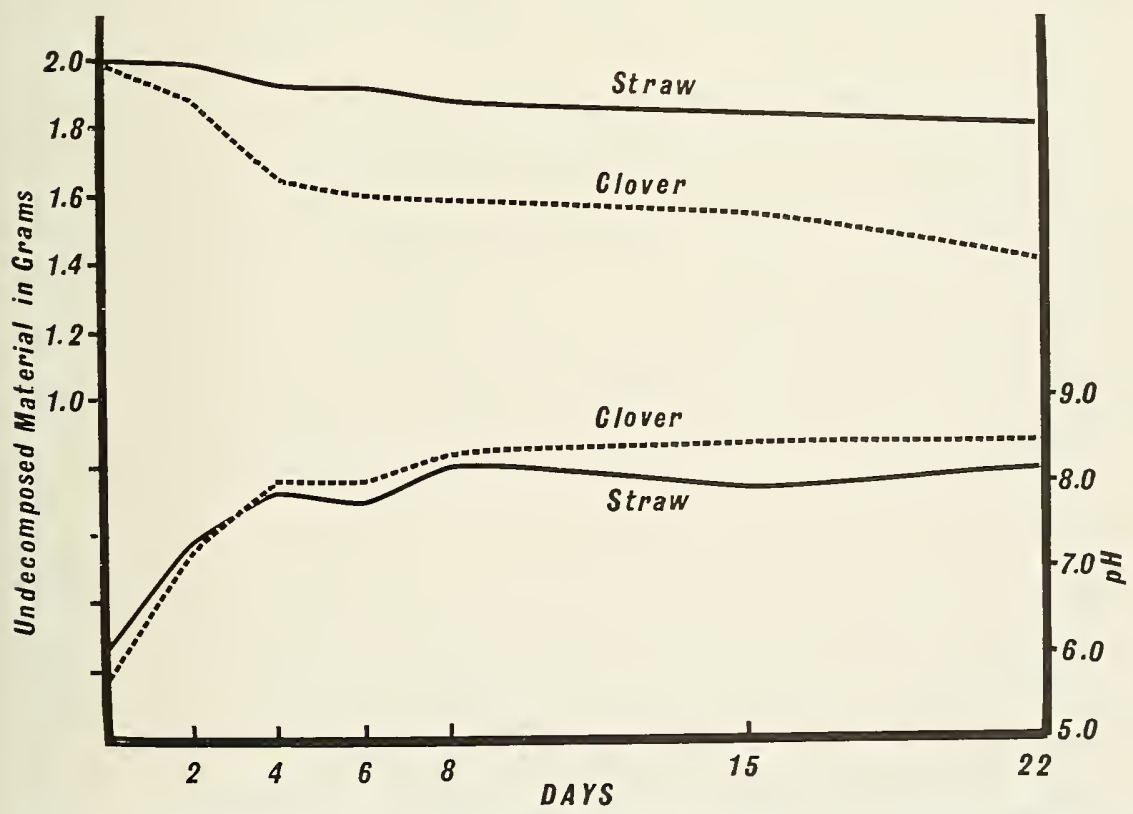

FIGURE 1. Decomposition of ground straw and ground red clover after different time intervals in farm pond water and the $\mathrm{pH}$ of the mixtures. 
than this amount of nitrogen creates at deliciency, thus the decomposition rate of the organic matter is retarded (Alexander 1961). Nitrogen, phosphorus, and potassium, singly and together, equivalent to a 5-10-10 (5\%, $\mathrm{N}-4.4 \% \mathrm{P}-8.3 \% \mathrm{~K}$ ) lertilizer, the amount based on the nitrogen deficit, were added to flasks containing ground straw and pond water. No dilference in the rate of decomposition was observed either among the various treatments or when compared with the control. The $\mathrm{pH}$ of the flask contents ranged from 7.6 to 7.9 at the beginning of the decomposition period and rose to approximately $\mathrm{pH} 8.55$ after 22 days.

Algae and potamogeton. The algae decomposed at a faster rate than did potamogeton. The rate was essentially equal to that of the red clover. After 22 days the amount of decomposition of the potamogeton was only slightly more than that of the straw.

\section{Nutritional Investigations and Nutritional Grouping}

One hundred twenty-four isolates were obtained at random from plates inoculated with water, secliment, and soil from pond 1 to study their nutritional requirements. Fifty-five of the isolates were from water, 37 from sediment, and 32 from soil.

Table 5 shows that most of the isolates required yeast extract for growth and the next largest group required yeast extract and soil extract.

Table 5. Nutritional Grouping of Bacterlal Isolates from Pond 1.

\begin{tabular}{|c|c|c|c|c|c|c|c|c|}
\hline \multirow{2}{*}{$\begin{array}{l}\text { Source of } \\
\text { Isolates and } \\
\text { Pigmentation }\end{array}$} & \multicolumn{7}{|c|}{ Nutritional Groups Media* } & \multirow{2}{*}{ Total } \\
\hline & B & $\mathbf{A}$ & G & AG & $\mathbf{Y}$ & $\mathbf{S}$ & YS & \\
\hline $\begin{array}{l}\text { Waler } \\
\text { White } \ldots \ldots \ldots \\
\text { Yellow } \ldots \ldots \\
\text { Orange } \ldots \ldots \\
\text { Pink } \ldots \ldots \ldots \\
\end{array}$ & $\begin{array}{l}0 \\
0 \\
0 \\
0\end{array}$ & $\begin{array}{l}0 \\
0 \\
0 \\
0\end{array}$ & $\begin{array}{l}0 \\
1 \\
0 \\
0\end{array}$ & $\begin{array}{l}0 \\
0 \\
0 \\
0\end{array}$ & $\begin{array}{r}22 \\
10 \\
0 \\
2\end{array}$ & $\begin{array}{l}0 \\
0 \\
0 \\
0 \\
\end{array}$ & $\begin{array}{l}8 \\
9 \\
2 \\
1 \\
\end{array}$ & $\begin{array}{r}30 \\
20 \\
2 \\
3\end{array}$ \\
\hline 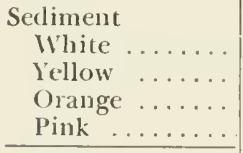 & $\begin{array}{l}0 \\
0 \\
0 \\
0\end{array}$ & $\begin{array}{l}1 \\
1 \\
0 \\
0 \\
\end{array}$ & $\begin{array}{l}0 \\
0 \\
1 \\
0 \\
\end{array}$ & $\begin{array}{l}2 \\
0 \\
0 \\
0\end{array}$ & $\begin{array}{r}18 \\
3 \\
0 \\
2\end{array}$ & $\begin{array}{l}0 \\
0 \\
0 \\
0\end{array}$ & $\begin{array}{l}3 \\
4 \\
2 \\
1\end{array}$ & $\begin{array}{r}24 \\
7 \\
3 \\
3\end{array}$ \\
\hline $\begin{array}{l}\text { Soil } \\
\quad \text { White } \ldots \ldots \ldots \\
\text { Yellow } \ldots \ldots \\
\text { Orange } \ldots \ldots \\
\text { Pinkt } \ldots \ldots \ldots \\
\end{array}$ & $\begin{array}{l}\text { 1) } \\
\text { () } \\
0\end{array}$ & $\begin{array}{l}0 \\
0 \\
0\end{array}$ & $\begin{array}{l}0 \\
0 \\
0\end{array}$ & $\begin{array}{l}1 \\
0 \\
0\end{array}$ & $\begin{array}{r}16 \\
4 \\
1\end{array}$ & $\begin{array}{l}0 \\
0 \\
0\end{array}$ & $\begin{array}{l}9 \\
1 \\
0\end{array}$ & $\begin{array}{r}26 \\
5 \\
1\end{array}$ \\
\hline Total $\ldots . . . \ldots$ & 0 & 1 & 2 & 3 & 78 & 0 & 40 & 124 \\
\hline
\end{tabular}

$\leftarrow$ No pink pigmented bacteria from the soil.

* $B=$ basal medium; $A=$ basal medium + amino acids; $G=$ basal medium + growlls factors: $A G=$ basal medium + amino acids + growl factors; $Y$ =basal medium + yeast extraci; $\mathrm{S}=$ basal medium + soil extracı; YS=basal medium + veast exiract + soil extract. 
There was little or no difference among the three groups according to source.

\section{Medium Concentration}

Seventy-one isolates from water, sediment, and soil of different ponds were inoculated into a series of diluted nutrient broth to determine their ability to multiply in different medium concentrations. The medium concentrations were as follows in parts per million: 8,000 (IX); 800, 80, $8,0.8$, and 0.08 ppm.

Although the number of isolates involved in this particular study was small, the data indicate a possibiiity that the bottom sediment isolates possess somewhat greater ability to grow and multiply in a dilute nutritional environment of this type than either those from water or soil. At a concentration of $80 \mathrm{ppm}$ the percentage of isolates growing were 68,42 , and 33 per cent from sediment, water, and soil, respectively.

\section{Physical and Chemical Characteristics of Pond Sediment:}

Some physical and chemical characteristics of bottom sediments for 11 of the 27 ponds sampled are presented in Table 6. The pond numbers correspond in all tables. The bacterial counts presented in other tables were made upon samples different from those used to determine the physical and chemical characteristics. With the exception of one pond, which is located near a strip-mine spoil area, the $\mathrm{pH}$ of all sediments are within the range of 6.2-7.8. Fourteen of the sediments were classed as sandy loams, loams, or loamy sands; only one sediment each was classed as a sand, silty clay loam, and clay.

Considerable variation is found in the results obtained from the chemical analyses. For example, the organic carbon ranged from 0.56 to 4.88 per cent; the active phosphorus range was from 2.1-9.6 $\mathrm{ppm}$; and the exchangeable potassium from $0.07-0.844 \mathrm{me} / 100 \mathrm{gm}$ soil. The ranges of the other exchangeable elements, as well as the exchange capacity of the soil, are equally great.

\section{Discussion}

The data obtained in this study on the numbers of bacteria in farm pond waters indicate that the bacterial density is much less than that in the bottom sediments and the soil around the pond. Although considerable variation occurs in the bacterial populations, the approximate range from 5,000 to 30,000 per milliliter cloes not seem particularly wide. The data suggest available nutrients may be a factor influencing bacterial density. Pond 6, for example, is usually partially covered with 


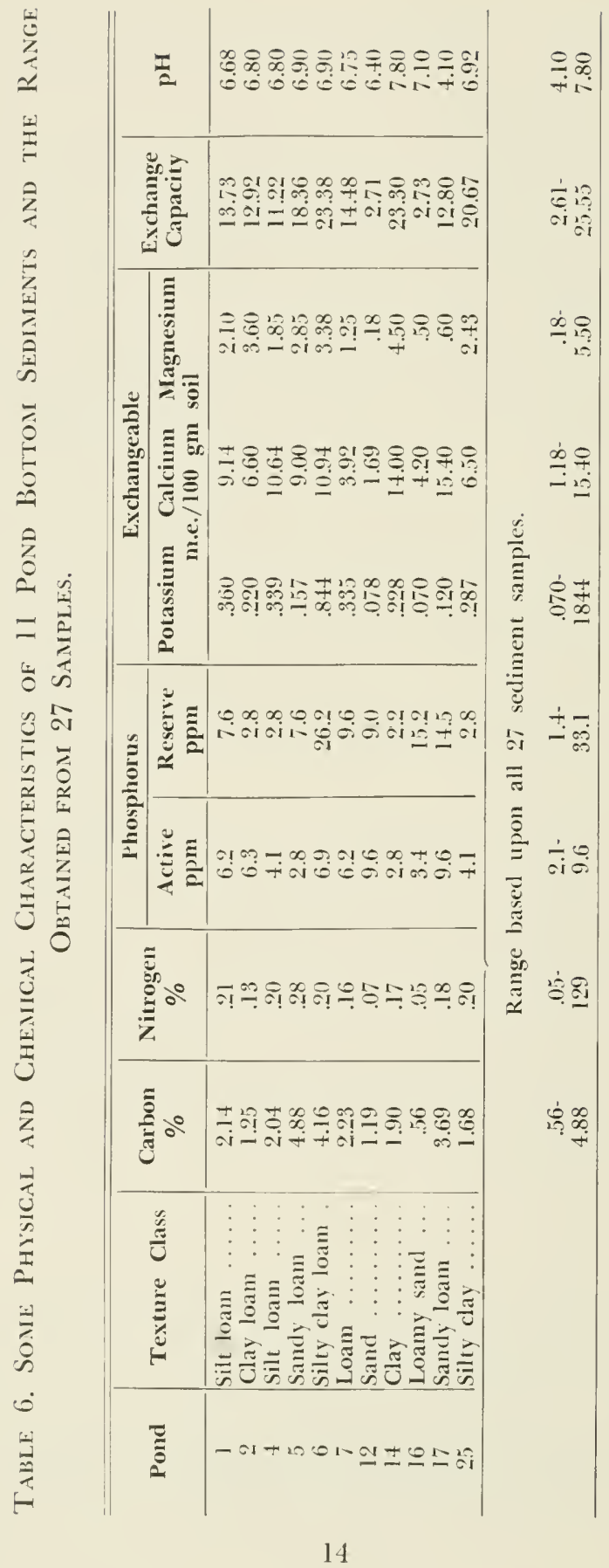


a thick algal mat, and in addition received run-off from a pasture grazed by cattle and sheep and also some run-off from the barn area. Pond 1, on the other hand, is mostly spring-fed; the water is clear and usually little algae are seen. The influence of nutrients is shown more by the data in Tables 4 and 5 where almost an equal number of samples were used.

The detailed data (Table 4) on numbers determined at various depths do not indicate any clear-cut correlation. There is a slight trend in this direction if all counts are totaled; the numbers increase with depth. More data are needed, however, before a correlation can be stated definitely. No correlation is evident between bacterial numbers and water temperature or $\mathrm{pH}$.

The overall data would indicate that the average farm pond is too shallow to show definite stratification, although some temperature differences are present. Kinney (1962) cited data obtained by Beall to show that differences in the dissolved oxygen exist between surface and bottom samples. Such variations, however, are not reflected in the numbers of bacteria per milliliter obtained in this study.

Snow and Fred (1926) found that the pigmented forms of bacteria constituted a high percentage of the bacterial flora indigenous to Lake Mendota. In this study, based upon the averages ('Table 1), the nonpigmented forms constituted 56 per cent of the total count, yelloworange forms 39 per cent, and red-pink 2.1 per cent. The first two percentages are near the 52 and 35 per cent as reported by Snow and Fred; however, they reported 11 per cent of the total as red-pink chromogens. Taylor (1940) pointed out that an incubation period of about 15 days at $20^{\circ} \mathrm{C}$ was needed in order for complete development of the pigmented bacteria. In the work reported here a narrower nonpigmented to pigmented ratio was obtained from the 14-day incubated plate counts than from plates incubated for the shorter periods (Table 4). Snow and Fred stated also that the percentage of pigmented forms in the water was somewhat greater than the percentage of pigmented soil forms as determined from Bergey's Manual of Determinative Bacteriology. The 1.47:1 ratio of nonpigmented to pigmented forms, as calculated from Table 1, is much narrower than the 6.55:1 ratio from soil (Table 3 ); this would seem to substantiate Snow and Fred's observation. It also should be pointed out that in this work the water samples and soil samples were collected at the same time and were plated and incubated using the same batch of medium and incubation location, time, and temperature

It is unlikely that excessive quantities of plant residues will be found in the average farm pond. Many ponds are so located that they receive considerable quantities of tree leaves. Another source of plant 
residues in ponds is algae and other water plants. If such materials fail to undergo decomposition they will accumulate on the bottom. Plant residues will decompose in these ponds as the data obtained using straw, red clover, algae, and potamogeton show (Table 2). This is especially true if the material is near the water's edge. In the deeper areas of the pond, residues which have settled to the bottom and become mixed in the sediment may undergo much slower decomposition. This may be the result of an oxygen deficiency (Kinney 1962) as it was evident that most of our bottom samples were anaerobic or nearly so, if odor can be used as a criterion.

It is also suggested that care needs to be exercised in taking sediment samples. The "can method" used in this work leaves much to be desired. Some subsamples had to be discarded during sampling as it was evident that more original bottom was brought up than secliment. Even so some original bottom material was collected, as evidenced in the number of samples whose texture class is on the sandy sicle of a loam. The sediment of the ponds has a tendency toward heavier soil texture. This would be expected as it would be the finer soil particles that would be blown onto the pond surface or washed in by water. The heavier material would settle near its entrance into the quieter water of the pond.

It would seem that a "farm" pond or ponds, under controlled activity and supervision, would be workable laboratories for the study of a number of aquatic microbiology problems. It appears that such ponds after a period of time have an indigenous microbial flora. 


\section{Literature Cited}

1. Alexander, M. 1961. Introduction to soil microbiology. John Wiley \& Sons, Inc., New York. 472 p.

2. Allison, L. E. 1960. Wet combustion apparatus for organic and inorganic carbon in soil. Soil Sci. Soc. Am. Proc. 24: 36-40.

3. Bennett, G. W. 1962. Management of artificial lakes and ponds. Reinhold Publishing Corp., New York. 283 p.

4. Bouyoucos, George J. 1936. Directions for making mechanical analyses of soils by the hyctrometer method. Soil Sci. 42: 225-229.

5. Boyd, William L., and Josephine W. Boyd. I963. A bacteriological study of an arctic coastal lake. Ecology 44: 705-710.

6. Burkholder, P. R., and G. H. Bornside. 1957. Decomposition of mass grass by aerobic marine bacteria. Bull. Torrey Botan. Club 84: 366-383.

7. Graham, E. R. 1959. An explanation of theory and methods of soil testing. Univ. Missouri Agr. Expt. Sta. Bull. 734.

8. Henrici, A. T., and Elizabeth McCoy. 1938. The distribution of heterotrophic bacteria in the bottom deposits of some lakes. Trans. Wisconsin Acad. Sci. 31: 323-361.

9. Kinney, Edward C. 1962. The potential importance of reservoirs. Pt. 111. Desirable reservoir features. W. Va. Conserv. 26(6): 6-10.

10. Lochhead, A. G., and F. E. Chase. 1943. Qualitative studies of soil microorganisms: V. Nutritional requirements of the predominant bacterial flora. Soil Sci. 55: $185-195$.

11. Malaney, G. W., H. H. Weiser, R. O. Turner, and Marilyn Van Horn. 1962. Coliforms, enterococci, thermodurics, thermophiles in untreated farm pond waters. Appl. Microbiol. 10: 44-51.

12. Potter, Louise F., and Gladys Baker. 1956. The microbiology of Flathead and Rogers Lakes, Montana. I. Preliminary survey of the microbial populations. Ecology 37: 351-355.

13. Snow, Laetitia M., and E. B. Fred. 1926. Some characteristics of the bacteria of Lake Mendota. Trans. Wisconsin Acad. Sci. 22: I43-154.

14. Taylor, C. B. 1940. Bacteriology of fresh water. I. Distribution of bacteria in English lakes. J. Hyg. 40: 616-640.

15. Taylor, C. B. 1942. Bacteriology of fresh water. IIl. The types of bacteria in English lakes and streams and their relationship to the bacterial flora of the soil. J. Hyg. 42: 284-296.

16. Van Slyke, L. L. 1939. Fertilizers and crop production. Orange Judd Publishing Co., Inc., New York. 493 p.

17. Zobell, Claucle E. 1946. Marine microbiology. Chronica Botanica Co., Waltham, Mass. 240 p. 
D8273 

